\title{
Asperger's syndrome. Characteristics and educational factors
}

\author{
El síndrome de Asperger. Características y factores educativos
}

\author{
Pilar Zamora López \\ University of Jaen, Jaen, Spain \\ pzl00002@red.ujaen.es
}

Fecha recepción: 01-04-2020

Páginas 19-25

Fecha aceptación: 20-05-2020

\begin{abstract}
.
Asperger's syndrome is diagnosed according to several behavioral patterns grouped together as diagnostic criteria. Behind the peculiar nature of each individual are underlying fixed cognitive aspects. This reflection examines the different cognitive mechanisms that are part of the teaching and learning process, which may constitute the essential aspects of this disorder. It discusses how mind theory, empathy, cognitive functioning, and executive functions affect the teaching and learning process. It also discusses the role that the integration of these students within the classroom plays, as well as the role played by the teacher within it. Our goal will be to inform the different groups about this syndrome, in addition to raising awareness that it is not a disease but a condition of life, in order to enable these people to adapt and develop in today's world.
\end{abstract}

Keywords: Asperger's Syndrome, cognitive mechanisms, inclusion, teaching and learning process

\section{Resumen.}

El síndrome de Asperger se diagnostica de acuerdo con varios patrones de comportamiento agrupados como criterios de diagnóstico. Detrás de la naturaleza peculiar de cada individuo hay aspectos cognitivos fijos subyacentes. Esta reflexión examina los diferentes mecanismos cognitivos que forman parte del proceso de enseñanza y aprendizaje, que pueden constituir los aspectos esenciales de este trastorno. Se examina la forma en que la teoría de la mente, la empatía, el funcionamiento cognitivo y las funciones ejecutivas afectan al proceso de enseñanza y aprendizaje. También se examina el papel que desempeña la integración de esos estudiantes en el aula, así como el papel que desempeña el profesor en ella. Nuestro objetivo será informar a los diferentes grupos sobre este síndrome, además de concienciar de que no es una enfermedad sino una condición de vida, para que estas personas puedan adaptarse y desarrollarse en el mundo actual.

Palabras clave: síndrome de Asperger, mecanismos cognitivos, inclusion, proceso de enseñanza y aprendizaje 


\section{1.-Introduction.}

Today there are discussion as to whether the Asperger's is an independent category, or, on the contrary, an element of the autism spectrum. The WHO ICD-10 classification presents similar categories and diagnostic criteria as referred to in DSMIV.

This term was designated by Hans Asperger as autistic psychopathy in 1943, just one year after Kanner gave his name to autism. Many of these characteristics have been recognized by the Austrian physician as a central axis of this disorder and are considered in force today. Lorna Wing (1981) resumes the diagnosis of this concept and begins to be considered for clinical use. It was not until 1994 that the CIE and DSM classifications begin to include it within generalized developmental disorders.

Asperger's Syndrome is a generalized developmental disorder characterized by social disturbances, deficit in playability, and repetitive behaviors. Its characteristics were not established until 1981 thanks to studies carried out by Dr. Wing. It was only included as a diagnosis in the DSM-IV in 1994.

In 1944, the first contributions made by Asperger appeared in Europe. Subjects diagnosed by Asperger under the name autistic psychopathy, exhibited behavior characterized by empathy and ability to make friends, poor and repetitive language, great interest in concrete subjects and blunder motor widespread. For Asperger's, these subjects could also show attention issues making their learning difficult. Since Asperger's work was written in German, they were not taken into account by psychiatrists and neurologists in many countries.

Therefore, when we talk about Asperger's Syndrome, we are referring to a developmental disorder that is characterized by social disturbances, communicative difficulties, little playability and repetitive aspects and movements. This disorder is found within the variety of generalized neurodevelopmental disorders (Etchepareborda 2007). It was considered independent when Lorna Wing in 1981 published her work on Asperger's syndrome: a clinical account, in which she involved research conducted by Asperger and also introduced Asperger's Disorder.

\section{2.-Diagnostic criteria.}

Asperger's Disorder is not recognized until is introduced by OMS into international Classification of Diseases. Secondly, the same was done with the Statistical Manual of Mental Disorders, in its fourth edition. At present, Asperger's Disorder remains classified in the CIE-10 manual but has disappeared in the last edition of the DSM (DSM-V) where the above categories are now presented grouped into one, differentiating three levels of affectation in a subject.

Artigas (2011), shows the neurocognitive characteristic of people with this disorder:

- Intelligence quotient compliant with mean 
- $\quad$ Good memory development

- $\quad$ Adequate language regarding semantics and morphosyntax, but alteration at pragmatic level.

- $\quad$ Difficulty to interpret nonverbal signs

- $\quad$ They talk about topic related to their interests

- $\quad$ Literal lenguage

- $\quad$ Globalization difficulties

- $\quad$ Shortage in executive functions

- Difficulty in social relationships

- $\quad$ Emotional and behavioral alterations

So, Asperger's Syndrome can be considered a bio-based neurodevelopmental disorder and is recorded within the Autism Spectrum Disorders group. It affects one in 110 children and occurs more in men than in women. At present diagnosis to identify Asperger's Disorder is strictly clinical. As reflected in the DSM-V rarely symptoms appear isolated, most subjects' manifest pathologies which are not part of this disorder. Normally it can appear, affective disorders, anxiety, attention deficit with and without hyperactivity, behavioral problems, motors and learning problems (Artigas, 2001).

Currently, it is still complicated to intervene, diagnose and detect these problems. Investigations by Beltran, Diaz and Zapata (2016) on Asperger's Syndrome showed that this syndrome is more usual than was initially studied.

Pineda and Puentes (2013) claim that one of the reasons Asperger's Syndrome may be affected is because it has symptoms that it shares with other diagnoses. On the other hand, Avila and Lara (2013) consider that there are other factors associated with pregnancy and labour are connected with the appearance of Asperger's Syndrome.

According to Naranjo (2014), studies focus their attention on cognitive aspects, the focus is on the components that configure the affective-relational area and that is part of the most important dimensions for advancement of human.

\section{3.-Theory of mind and empathy.}

An important factor that is strongly related to Asperger's Syndrome is the "Theory of Mind". This concept is the basis for self-knowledge and knowledge of others. In relationships it is important that the individual gain feelings and emotions in others in order to respond through appropriate behaviors. Maseda (2013) and Mazza (2017) consider these aspects characteristic of Asperger's Syndrome, considering that socialization is affected in both cases.

For Cobo and Moran (2011) the theory of the mind is the ability of human to create an internal representation of one's mental states and others. To get a low score on the assessment of this field is related to Autism Spectrum Disorder (Young \& Barnett, 
2017). As a result, those within this field will present difficulties in the construction of the theory of mind because this theory is the result of interaction thought and language in the social sphere.

Moreover, for Naranjo (2014), empathy and theory of mind are essential for the implementation of social skills. According to this author Asperger's Syndrome is interpreted as someone who is not able to understand feelings, emotions and thoughts in others people. "Individuals can't imagine what's going on in the mind, they can't anticipate their response, and they show numerous difficulties in integrating aspects which require a degree of cognition and affectivity in a situation" (p. 8).

An advanced study is needed whose objetive is to show the relationship between theory of mind and empathy, mainly in Asperger's Syndrome.

It is very important to know how socialization processes effects, as well as to determine what is new regarding the research related to Asperger's Syndrome, so it can favor early intervention, improving the quality of life of these people in the social, family and educational fields.

\section{4.-Cognitive functioning.}

In the development of language, the first years will highlight the use of simple words and around the age of three they already start to use phrases with communicative sense. Therefore, the use of language provides sufficient evidence to rule out a delay in the acquisition of other more formal aspects. Language development is essential for the individual function properly on a social level. These skills concentrate a range of communicative skills, including the act of speech, the use of language, and the roles that are assumed in social communication (Martín-Borreguero, 2005).

According to Castro and Vicente (2014) people who have this syndrome show adequate processes in phonology, morphosyntax and vocabulary, the difficulties manifested in communication are mostly due to deficits in social relations.

Following Borreguero (2005) the data obtained have been analyzed and show that there is a pattern in the development of these subjects that is involved in the acquisition and development of language. In despite of, most these people get to an appropriate level of functioning and sometimes it achieves a significant degree of progress. They have a big hearing memory capacity that allows them to retain high amounts of information. In contrast, we can find some difficulties in understanding abstract concepts, as well as in terms related to space and time.

\section{5.-Executive functions.}

According to Bryson and Smith (2008), executive functions are within a group aimed at depriving the individual of automations and regulating thinking which is aimed at achieving objectives. Within this block we can find working memory, sef-refulation, cognition and organization. All of them act together, so that the various processes that influence at the cognitive level can be controlled and coordinated. 
Executive functions are considered an activity carried out by the frontal lobes together with other areas that contribute to the realization of multiple tasks: to coordination, to select strategies to achieve objectives, as well as the obtaining of information from the outside world (Diamond, 2002).

For this reason, has been linked Asperger's Syndrome with clinical diagnoses, focusing on exploring memory, language and attention. The starting point was executive functions which are considered an important factor in establishing the cognitive mechanisms of this syndrome (Carlson \& Moses, 2001).

\section{6.-Asperger syndrome in primary education.}

Can we talk about school integration? For Attwood (2000), cognitive difficulties together with previously mentioned characteristics, make it inevitable to start schooling and collaborate with appropriate professionals, especially in adolescence. This intervention should not be limited to school, it will be necessary in the familiar environment. The work of the professionals will be to advise the teachers, the peer group and all those people who take part in the context of this student.

On the other hand, Casanova (2000) proposes that before proposing a change at the school level, it is necessary to mediate on the posible procedures offered by the educational system. Riviere (2001) suggests that the integration of this group of people carries with it two important features: diversity and personalization of teaching. Systems designed for homogeneous population groups do not provide answers to those people whose development does not come to the model of human development.

Regarding to the peer group who are part of the student's school context, it is necessary to teach them tools so that they understand the situation of their classmates and they can support their learning at all times. Generally, it is intended that students successfully integrate into the school context, Attwood (2000) believes that knowing the characteristics of students with Asperger's Syndrome is an important factor to consider.

For Riviere (2001), any professional who includes a student with Asperger's Syndrome in the classroom must have the support of the peer group within the classroom; for example, he must instruct the integrated person to observe the other schoolmates and imitate their behavior, considering that the behaviors carried out by the rest of the schoolmates are appropriate. The teacher Will be able to make games in class in which the organization of the students in small and big groups, all of them supervised by the same and guaranteeing cooperation. Also, it is important to incorporate objectives and content related to Asperger's Syndrome promoting tolerance, respect and inciting the implementation of social skills. All this, Will help other classmates to improve the way of acting in front of the integrate person.

Teachers are responsible for providing ways to teach students other forms of solving problem, facilitating the exchange of information and making it part of all the center's 
activities. It is convenient to supervise the Behaviour of all students during break, since it is the moment in which the social interaction skills take place (Attwood, 2000).

\section{7.-Conclusion.}

Finally, I believe that we should be more flexible in using school methodologies. We can open our minds to new ways of understanding education to adapt to differences of each individuality, introducing new methods that can remarkable and effective for the rest of the class.

Inclusion is based on principles of individualization and standardisation, achieving as an objective that conditions which the students learns are as normal as possible, in this way it is possible to develop the student's potential.

Therefore, I consider it appropriate to devote more time and resources to our training, understand the difficulties that arise daily in the field of education, due to we do not stop finding impediments in this process, because competition and solidarity are positioned above communication. The future must be aimed towards an Education based on diversity, eliminating homogeneous trends and making way for the most heterogeneous.

\section{8.-References.}

Ávila, J., \& Lara, D. (2013). Factores epigenéticos de los trastornos generalizados del desarrollo. Análisis comparativo entre Autismo y Síndrome de Asperger. Colombia: Ediciones CUR.

Artigas-Pallarés, J. (2001). Las fronteras del autismo. Revista de Neurología Clínica, 2, 211-224.

Attwood, T. (2000). Estrategias para mejorar la integración social de niños con síndrome de asperger. Autismo, 4(1), 85-100.

Beltrán, C., Díaz, L.A., \& Zapata, M. (2016). Síndrome de Asperger: aspectos teóricos y prevalencia en dos ciudades de Colombia. Psicogente, 20(38), 321-326.

Bryson, S.E., \& Smith, I.M. (2008). Executive Function in Preschoolers: A Review Using an Integrative Framework. Psychological Bulletin, 134(1), 31-60.

Casanova, M. (2000). La integración educativa del niño autista. Madrid: Asociación de Padres de Niños Autistas.

Castro, S.L., \& Vicente, S.G. (2014). Atypical prosody in Asperger syndrome: Perceptual and acoustic measurements. Journal of autism and developmental disorders, 44(8), 1972-1981. 
Carlson, S.M., \& Moses, L. J. (2001). Individual differences in inhibitory control and children's theory of mind. Child Development, 72, 1032-1053.

Cobo, M., \& Morán, E. (2011). El síndrome de Asperger. Intervenciones psicoeducativas. Zaragoza: Asociación Asperger y TGD de Aragón.

Diamond, A. (2002). Normal development of prefrontal cortex from birth to young adulthood: Cognitive functions, anatomy, and biochemistry. London: Oxford University Press. 